\title{
パルス反応性スパッタリングによる $\mathrm{Fe} / \mathrm{Fe}-\mathrm{O}$ 人工格子膜作成と界面の熱安定性
}

\author{
平本 雅祥*.松川望*.市川 洋* \\ 飯島 賢二**榊間 博*
}

（受理1998年 1 月 26 日，掲載決定1998年 5 月 2 日）

\begin{abstract}
Thermal Stability of the Interface of $\mathrm{Fe} / \mathrm{Fe}-\mathrm{O}$ Artificial Superlattices
Masayoshi HIRAMOTO, Nozomu MATSUKAWA, Yo ICHIKAWA, Kenji IIJIMA and Hiroshi SAKAKIMA
\end{abstract}

Central Res. Labs., Matsushita Electric Industrial Co., Ltd., 3-4 Hikaridai, Seika-cho, Kyoto 619-02, Japan

(Received January 26, 1998, Accepted May 2, 1998)

\begin{abstract}
Pulse reactive sputtering (PRS) using a metal target and reactive gas as $\mathrm{O}_{2}$ or $\mathrm{N}_{2}$ is one of the fast deposition method to prepare multilayered films composed of metallic layers and metallic compound layers which contain the elements of the reactive gases. We have investigated the formation of the layered structures of $\mathrm{Fe} / \mathrm{Fe}-\mathrm{O}$ films by using optical emission spectra from plasma in the sputtering process. We successfully prepared $\mathrm{Fe} / \mathrm{Fe}-\mathrm{O}$ multilayers with precise periodicity of nanometer level with the low activated oxygen plasma condition. Thermal stability of the layered structure and the soft magnetic properties of $\mathrm{Fe} / \mathrm{Fe}-\mathrm{O}$ films were studied by XRD and the measurements of permeability after thermal treatments at several temperatures. It was observed that the periodicity of the structure begun to destroy and the permeability was degraded at around $400^{\circ} \mathrm{C}$. The layered structure of $\mathrm{Fe} / \mathrm{Fe}-\mathrm{O}$ films thought to be tougher than that of $\mathrm{Fe} / \mathrm{SiO}_{2}$ films against the thermal treatment.
\end{abstract}

\section{1. はじめに}

磁性金属や磁性金属合金（M）と化合物の積層膜 ( $\mathrm{M} /$ 化合物) の積層界面の制御は, 磁気へッドに用いら れるメタルコアや, トンネル効果を用いた薄膜電子デバ イス等の高性能化に必要な要素技術の一つである. 界面 制御には，作製手法及び組成系の 2 つの視点からのアプ ローチがある. 組成系からは, $\mathrm{M} /$ ヘテロ化合物 $\left(\mathrm{SiO}_{2}, \mathrm{SiC}\right.$ 他) ${ }^{1,2)}$ や， M/M-(N, C) 系についての報告 ${ }^{3,4}$ があり， 前者については表面・界面エネルギーの視点から, M 層に対する化合物層の層構造の安定性が調べられてい

\footnotetext{
* 松下電器産業(
} 4)
に解明されていない.

$\mathrm{M} / \mathrm{M}$ 化合物積層膜界面を作製する手法の一つとし て，パルスリアクティブスパッタリング法（PRS 法） がある5). PRS 法とは，M 層形成中に，パルス的に反 応性ガスを導入して $\mathrm{M}$ 化合物層を作製する反応性スパ ッタリング法の一種である. PRS 法は単一のターゲッ トから $\mathrm{M} / \mathrm{M}$ 化合物積層膜を連続成膜でさ, 複数のター ゲットを用いる必要がない。またプリスパッタが不要で あるために積層膜を単層膜と同程度の速度で成膜できる ので生産性も高い。域膜速度が速いことから，体積 あたりの界面比率が高い（すなわち周期が短い）積層膜 作製が容易で，X線回折法などによる広範囲での非破 壊分析が容易であるという利点もある。しかしながら， 
積層膜の周期が数 $\mathrm{nm}$ 程度に短くなると, パルスタイミ ングからずれて装置内に残留する反応性ガスのために, 明瞭な周期構造を作製することが困難となることが予想 される。

本研究では, まず反応性ガスのパルス導入, 停止に伴 らプラズマ状態の時間的変化を観察することで, 数 $\mathrm{nm}$ 程度の比較的周期が短い積層膜の作製条件を調べた。つ ぎに $\mathrm{M} / \mathrm{M}-\mathrm{O}$ 系として $\mathrm{Fe} / \mathrm{Fe}-\mathrm{O}$ 積層膜を作製し，微細 構造と界面の熱安定性をX 線及び磁気特性から評価し た. $\mathrm{Fe}-\mathrm{O}$ 化合物は, 酸化䨌囲気によってへマタイト, マグネタイト，ウスタイトと呼ばれる複数の相を持つ. このために界面の熱安定性の挙動も興味深い。また $\mathrm{M}-$ $\mathrm{O}$ 系は $\mathrm{M}-(\mathrm{N}, \mathrm{C})$ 系に比較して, 磁気的, 電気的物性 の選択性が広いといら特徵を持つ。一般に, 磁性積層膜 の磁気特性は, 界面の電気的, 磁気的な結合状態により 大きく変化することが知られている. 従って $\mathrm{M} / \mathrm{M}-\mathrm{O}$ 系は, 層界面安定性を磁気特性の側面から間接的に評価 することが可能であると考えらる．例えば，X線回折 には向かない数十 $\mathrm{nm}$ 以上の長周期の積層膜に拉いて も, 磁気特性の測定から, 界面持よび微細構造の状態を 間接的に考察できるものと期待できる.

\section{2. 実験方法}

\section{1 パルス反応性スパッタリング（PRS）}

PRS は通常の RF (13.56 MHz) マグネトロンスパッ タ装置を用い，不活性ガス中で放電中に，間欠的に反応 性ガスを導入するスパッタリング法である。本実験では 不活性ガス及び反応性ガスとして，それぞれ純度 99.9999\%の $\mathrm{Ar}$ 及び $\mathrm{O}_{2}$ ガスを用いた。 また，間欠的に 導入する $\mathrm{O}_{2}$ ガスを予備排気することで, 導入 $\mathrm{O}_{2}$ ガス 圧とチャンバー内圧力の圧力差を小さくした. ターゲッ トには, 直径 $76 \mathrm{~mm}$, 厚み $3 \mathrm{~mm}$, 純度 $99.9 \%$ の いた。 また基板には非磁性セラミックス（ $\mathrm{Ti}-\mathrm{Mg}-\mathrm{Ni}$ O）基板を用いた．代表的な放電ガス圧，放電電力密度 は $\mathrm{Fe}$ 層, $\mathrm{Fe}-\mathrm{O}$ 層ともに0.4 $\mathrm{Pa}, 8 \mathrm{~W} / \mathrm{cm}^{2}$ である.

成膜は室温で行った。作製した試料の膜表面には酸化 防止のために $10 \mathrm{~nm} の \mathrm{Al}_{2} \mathrm{O}_{3}$ 膜を形成した.

\section{2 評価方法}

プラズマ状態は絶縁した基板ホルダーとアース間に発 生する電位（以下，基板電位）の測定，及びパラバマ分 光による $\mathrm{Ar}^{*}(772.2 \mathrm{~nm})$ 及び OI $(777.1 \mathrm{~nm})$ 発光強 度により調べた. プラズマ分光はコバールのガラス空を 通して基板上約 $1 \mathrm{~cm}$ の位置での発光を光ファイバーで 分光器に導入し計測した. 試料の磁気特性として基板面 に平行な透磁率を測定した. 透磁率はネットワークアナ ライザーと接続したフェライトヨーク上に測定試料をセ

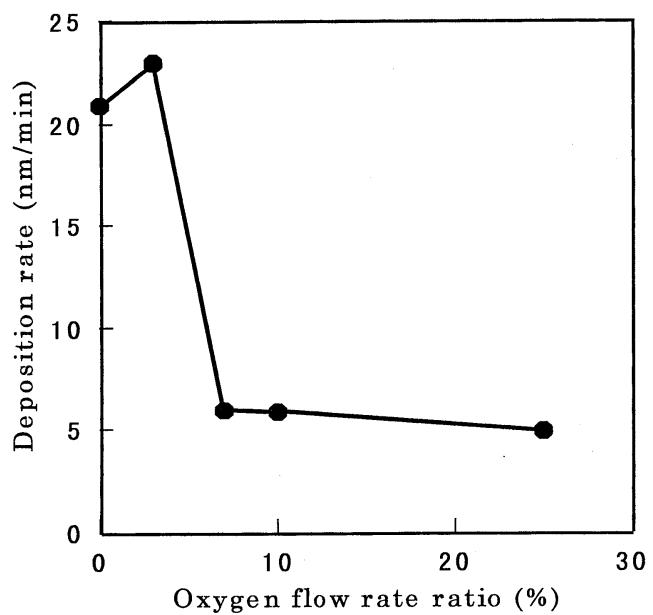

Fig. 1 Relation between deposition rate of $\mathrm{Fe}^{-}-(\mathrm{O})$ and oxygen gas flow rate ratio.

ットし, 試料セット前後のインピーダンスの変化率から 換算した. 界面の熱安定性を調べるため, 微細構造につ いては, 試料を所定の温度で熱処理後, X 線回折法を 用いて調べた。測定はすべて室温で行った。

\section{3. 実験結果及び考察}

\section{1 定常状態での酸化物成膜速度とプラズマ状態}

はじめに, PRS 法との比較のために, 定常状態での 反応性スパッタリングについて, $\mathrm{Fe}-\mathrm{O}$ 成膜速度と全ガ ス流量に対する $\mathrm{O}_{2}$ 流量比 $\left(\mathrm{O}_{2} /\left(\mathrm{O}_{2}+\mathrm{Ar}\right)\right)$ の関係を調 ベた. Fig. 1 に示すように, $\mathrm{O}_{2}$ 流量比 $3 \%$ では, $\mathrm{Ar} の$ みでスパッタした $\mathrm{Fe}$ 単層膜よりも成膜速度が僅かに速 く, また流量比 $7 \%$ 程度以上では急激に減少する. X 線回折の結果, $3 \%$ の $\mathrm{O}_{2}$ 流量比で作製した膜からは, $\mathrm{Fe}$ 単層膜よりも広い半值幅を持つ, Fe 110 回折線が観 察された. 従って, 流量比 $3 \%$ で作製した膜では, $\mathrm{Fe}^{-}$ $\mathrm{O}$ 化合物と微細な Fe 結晶の複合相が混在しているもの と考兄られる.この流量比での成膜速度の上昇は主に $\mathrm{Fe}$ 酸化物形成による体積膨張が原因と考えられる。一 方, 流量比 $7 \%$ 以上で作製した膜では，(110)面からの 回折がほとんど観察されず, アモルファス状の $\mathrm{Fe}-\mathrm{O}$ 膜 が形成されていると考えられる．この流量比での成膜速 度の減少は, ターゲット表面に酸化物層が形成されスパ ッタリング率が低下したこと, 及びArに比ベスパッタ

リング率が低い $\mathrm{O}_{2}$ の分圧の増加が原因と考光られる.

次に，それぞれの $\mathrm{O}_{2}$ 流量比での発光スペクトル，OI $(777.1 \mathrm{~nm}), \mathrm{Ar}^{*}(772.2 \mathrm{~nm})$ と基板電位を測定した (Fig. 2). OI 発光強度はターゲット上あるいは基板上 


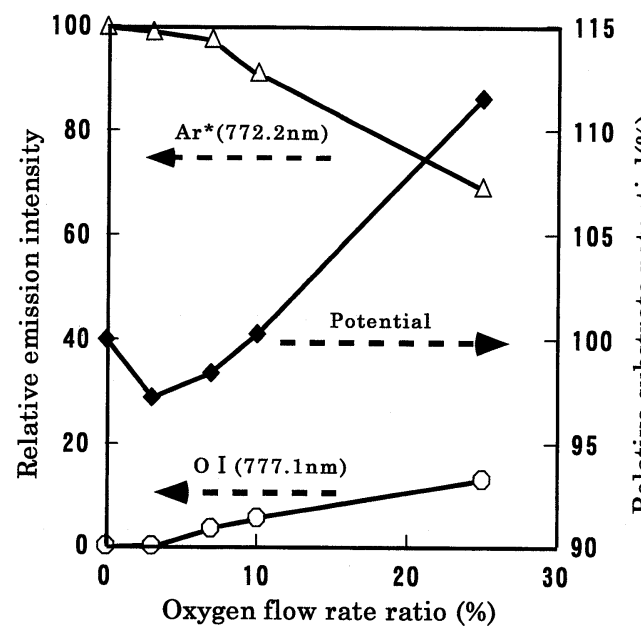

Fig. 2 Relative substrate potential and relative emission intensities of $\mathrm{OI}$ and $\mathrm{Ar}^{*}$ versus oxygen gas flow rate ratio.

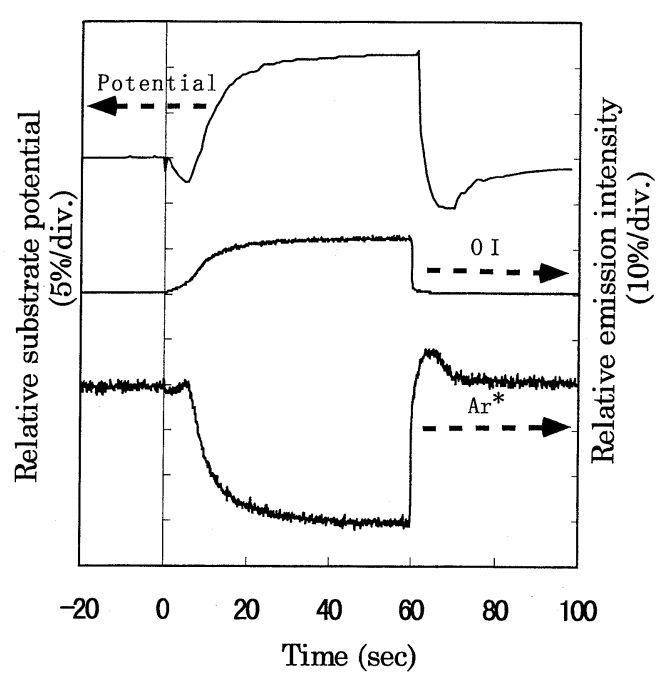

Fig. 3 Time profiles of relative substrate potential and relative emission intensities of $\mathrm{OI}$ and $\mathrm{Ar}^{*}$ before/after introducing pulsed oxygen gas.
での Fe の酸化のし易さの目安を，また $\mathrm{Ar}^{*}$ 発光強度は スパッタリング率の程度の目安を与兄るものと考兄られ る. 一方, 基板電位は, 実際に堆積中の膜自体が受ける プラズマの影響を間接的に知る指標となる. 発光強度及

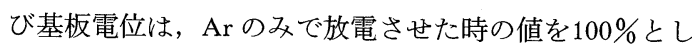
てそれぞれ規格化してある. $\mathrm{Ar}^{*}$, 及び $\mathrm{OI}$ の発光強度 は $\mathrm{O}_{2}$ 流量比の増加に伴い, それぞれ単調に減少, ある いは単調に増加する。一方, 基板電位は, $\mathrm{O}_{2}$ 流量比の 変化に対し, 一旦減少した後に増加する特徵的な変化を 示している.

\subsection{PRS におけるプラズマ状態の過渡変化}

次に, PRS での OI, 及び $\mathrm{Ar}^{*}$ の発光強度, 及び基板 電位の変化を調べた. Fig. 3 に, パルス $\mathrm{O}_{2}$ ガス導入時 間（以下，パルス幅）を60 secに選んだ時の測定結果を 示す.ここでパルス状の $\mathrm{O}_{2}$ 流量比は $25 \%$ とした. この 值は前節で示したように, 定常状態の反応性スパッタで は, アモルファス状の $\mathrm{Fe}-\mathrm{O}$ 膜を形成する条件である. 尚, ガス導入は OI 発光スペクトルが観測されなくなる までターゲット表面を充分に Arスパッタクリーニング した後に行った。図のように各波形には, $\mathrm{O}_{2}$ ガス導入, 停止直後に過渡的変化が観察される. 各波形には, 本装 置固有の排気特性が，プラズマの時間的変化に反映され たもの思われる. 時間順に考学ると, (1) $\mathrm{O}_{2}$ ガス導入に 伴 $\mathrm{O}_{2}$ 分圧, 及び放電ガス圧の変動, (2)装置内でのガ ス拡散過程と導入 $\mathrm{O}_{2}$ ガスのプラズマ化に要する過渡時 間, (3)反応性スパッタリングの定常化, (4) $\mathrm{O}_{2}$ ガス停止 の反動により, 装置内に流入する不活性の $\mathrm{Ar}$ ガスの瞬

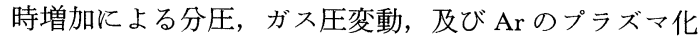
に要する過渡時間，(5)ターゲット上に形成された酸化物 のスパッタリングを含む装置内の残留 $\mathrm{O}_{2}$ ガスの排気過 程が挙げられる．特に，(1)，(2)（4)，(5)）の状態に対応 する, ガス導入 (停止) 直後では, $\mathrm{O}_{2}$ 流量比が $25 \%$ （０％）であるにも関わらず，弱いOI 発光が観察され， 基板電位が，ガス導入以前の值より低い值を示してい る. 基板電位の低下については, ガス導入停止に伴うプ ラズマ変動の影響を含んではいるものの, これらの状態 は, 定性的には, Fig. 1 及び 2 の $\mathrm{O}_{2}$ 流量比が $10 \%$ 以下 の低 $\mathrm{O}_{2}$ 流量比時に和いて見られたプラズマ状態（以 後, 低酸素プラズマ状態と呼ぶ）と同様の状態にあるも のと考光られる.

Fig. 4 及びFig. 5 と, 導入 $\mathrm{O}_{2}$ ガスのパルス幅を 5 $\sec$ から $60 \mathrm{sec}$ まで変えた時の, 基板電位及び OI の発光 強度の時間的变化を示す. 基板電位は, ガス導入停止 後, 導入以前の電位に回復するには, 数 10 秒程度を要す ることがわかるまたパルス幅が短くなるにつれ，基板 電位がガス導入以前よりも低い值を示す割合が増加する 傾向が見られる.一方, 発光強度は, パルス幅が 60,30 $\sec$ ではガス導入停止後, 数秒程度残存 OI 発光が観察 されるものの，パルス幅が $5 \mathrm{sec}$ 程度では汪とんど見ら れない，またパルス幅が短くなるにつれ，発光強度が弱 くなる傾向があることがわかる. 従って, 本装置では, 比較的明瞭な周期構造を持つ, 数 $\mathrm{nm}$ 周期の $\mathrm{Fe} / \mathrm{Fe}-\mathrm{O}$ 積層膜を作製するためには，少なくともパルス幅を10 


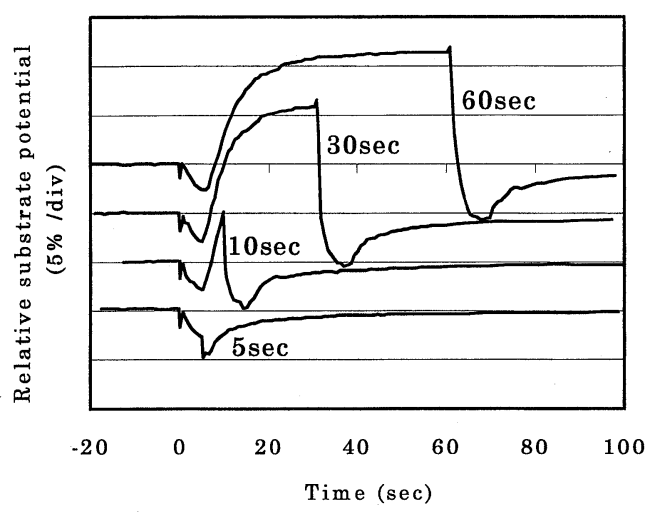

Fig. 4 Time profiles of relative substrate potential before/after introducing pulsed oxygen gas with several pulsed widths.

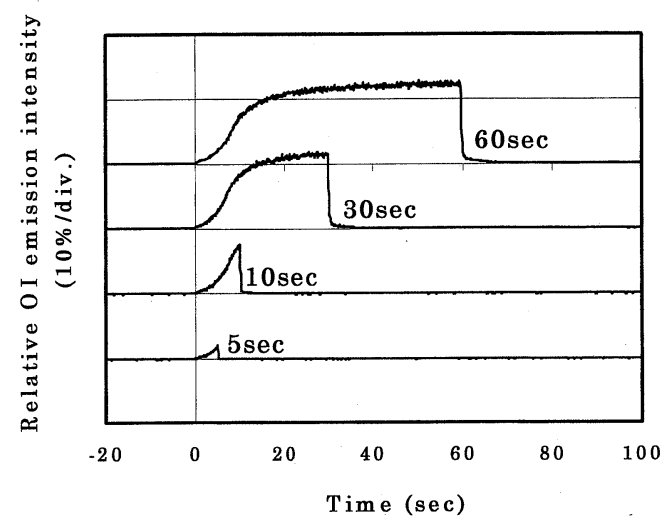

Fig. 5 Time profiles of relative OI emission intensity before/after introducing pulsed oxygen gas with several pulsed widths.

sec 以下の低酸素プラズマ状態で作製する必要があると 考光られる。

\subsection{PRS における見かけの酸化物成膜速度}

PRS で連続成膜した積層膜の酸化物層の厚みは, 成 膜時の酸素プラズマ密度, 抢よび残留ガス, 残留酸化物 を含めた $\mathrm{O}_{2}$ ガス滞在時間が不明であるために正確に見 積もる事が難しい.PRS 法で作製した $\mathrm{Fe}-\mathrm{O}$ 層の見か けの層厚, 及び成膜速度を求めるために以下の方法を用 いた。

まず， $\mathrm{Fe}-\mathrm{O}$ 層形成のパルス幅 $\mathrm{T}_{\mathrm{Ox}}$ を固定し， $\mathrm{Fe}$ 層 の成膜時間 $\mathrm{T}_{\mathrm{Fe}}(\mathrm{sec})$ を変光た積層膜を数種類, 数 100 周 期形成した。ここで $\mathrm{Fe}$ 層の成膜時間は, 残留酸素が各 周期にまたがって存在しない程度に十分長い時間を選ん だ. 触診式段差計で測定した総膜厚から 1 周期あたりの

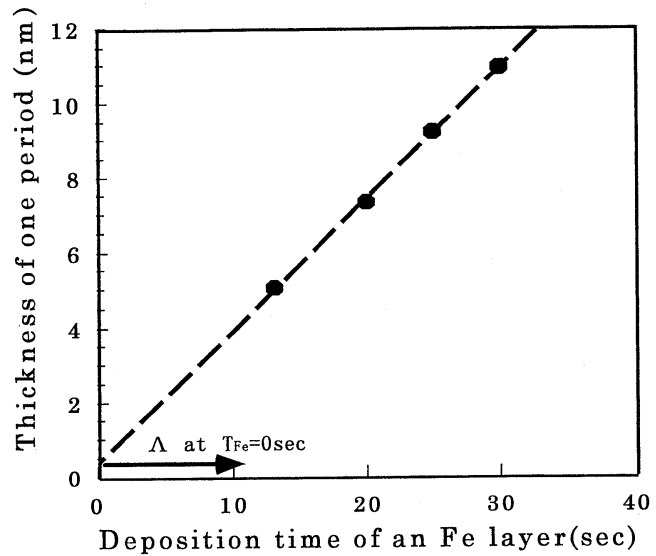

Fig. 6 Relation between deposition time of a Fe layer, $\mathrm{T}_{\mathrm{Fe}}$ and thickness of a period, $\Lambda$ of $\mathrm{Fe} / \mathrm{Fe}-\mathrm{O}$ layers.

厚み $\Lambda(\mathrm{nm})$ を求めこれを縦軸にとった． $\Lambda$ 対 $\mathrm{T}_{\mathrm{Fe}}$ の実 験結果から外插して, Fe-O 層厚みを求めた。 Fig. 6 に，パルス状の $\mathrm{O}_{2}$ 流量比を $25 \%$ とした $\left[\mathrm{Fe}\left(\mathrm{T}_{\mathrm{Fe}}\right) / \mathrm{Fe}-\mathrm{O}\right.$ $\left.\left(\mathrm{T}_{\mathrm{OX}}=1 \mathrm{sec}\right)\right] \times(150 \sim 800)$ 周期で作製した積層膜の $\Lambda$ を示寸. 図の外挿值から $\mathrm{Fe}-\mathrm{O}$ 層の 1 層当たりの膜厚は 約 $0.4 \mathrm{~nm}$ と求められる.これは $\mathrm{O}_{2}$ 流量比 $25 \%$ で成膜し た $\mathrm{Fe}-\mathrm{O}$ 単層膜の成膜速度の約 5 倍で, むしろ $\mathrm{O}_{2}$ 流量 比 $3 \%$ での成膜速度に近く, パルス幅が短い状態では, 低酸素プラズマ状態にあるといら前述の実験結果と定性 的に一致する。また 1 周期当たりの厚みから $\mathrm{Fe}-\mathrm{O}$ 層の 概算厚みを引いて求めた $\mathrm{Fe}$ 層の成膜速度は $\mathrm{Fe}$ 単層膜 の成膜速度と一致した。

\section{$3.4[\mathrm{Fe}(4.6 \mathrm{~nm}) / \mathrm{Fe}-\mathrm{O}(0.4 \mathrm{~nm})] \times 800$ 皘層膜の周 期性}

Fig. 7 亿，前節の条件で作製した $\left[\mathrm{Fe}(4.6 \mathrm{~nm}) / \mathrm{Fe}^{-}\right.$ $\mathrm{O}(0.4 \mathrm{~nm})] \times 800$ 積層膜を $300^{\circ} \mathrm{C} て ゙$ 熱処理した後の X 線 回折パターンを示寸．低角から高角域に現れるブラッグ ピークから，長周期構造を持つ人工格子ができて招り， また中高角域にみられる $\mathrm{Fe} 110$ 怙よび Fe200反射からの 回折線から Fe 層は結晶質であることがわかる，低角域 でのブラッグ則は物質の複素屈折率 $\mathrm{n}=1-\delta+\mathrm{i} \beta$ とすれ ば簡単には次式で表せられることが知られている。

$$
\sin ^{2} \theta=\mathrm{m}^{2}(\lambda / 2 \Lambda)^{2}+2 \delta
$$

ここで $\theta, \mathrm{m}$ はそれぞれ回折角, 回折反射次数を表 す. Fig. 7 の $\mathrm{m}^{2}-\sin ^{2} \theta$ プロットを最小二乗法のフィッ テイングから求めた $\delta$ は $2.86 \times 10^{-5} て ゙ \Lambda$ は $5.3 \mathrm{~nm}$ であ った。触針段差計から求めた総膜厚から計算した $\Lambda(5$ $\mathrm{nm})$ は，膜厚分布を含めた誤差範囲が士5％程度である ので，PRS 法を用いて作製した $\mathrm{Fe} / \mathrm{Fe}-\mathrm{O}$ 積層膜は，高 


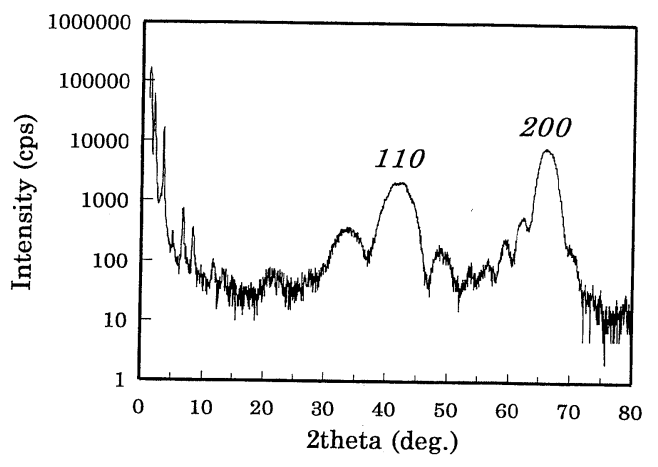

Fig. 7 X-ray diffraction pattern of $(\mathrm{Fe} / \mathrm{Fe}-\mathrm{O}) 800$ layers after $300^{\circ} \mathrm{C}$ annealing.

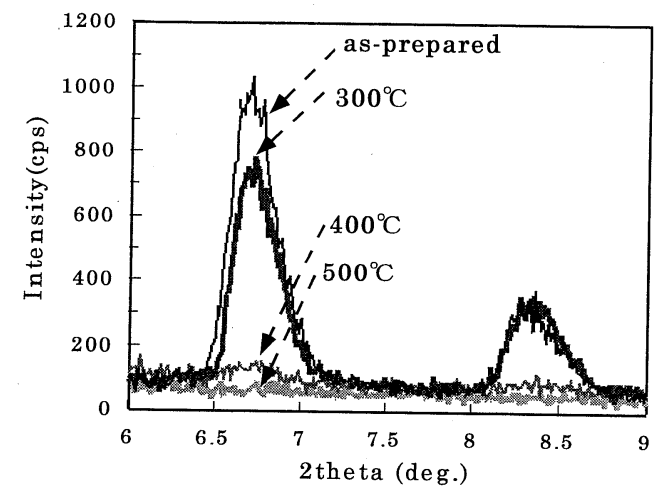

Fig. 8 Low angle $\mathrm{X}$-ray diffraction patterns of $(\mathrm{Fe} /$ $\mathrm{Fe}-\mathrm{O}) 800$ layers after annealing at several temperatures.

速成膜であるにも関わらずパルスタイミングに対応した 周期を持つ人工格子になることがわかる.

\section{$3.5[\mathrm{Fe}(4.6 \mathrm{~nm}) / \mathrm{Fe}-\mathrm{O}(0.4 \mathrm{~nm})]$ 人工格子膜の界 面の熱変化}

作製した $\mathrm{Fe} / \mathrm{Fe}-\mathrm{O}$ 人工格子膜の界面の熱安定性につ いて, X 線回折及び磁気測定により調べた。試料を真 空熱処理炉で, $300^{\circ} \mathrm{C} \sim 500^{\circ} \mathrm{C}$ 采 $100^{\circ} \mathrm{C}$ 刻久で30分間熱 処理した後の，小角域におけるブラッグピークの強度変 化を Fig. 8 亿示す. 回折線として, 試料取付角度によ る強度誤差の影響が比較的少ない 4 次及び 5 次のピーク を選んだ. 図のよ $5 に 300^{\circ} \mathrm{C}$ 熱処理では, 成膜直後に 比べ強度変化は少なく, $400^{\circ} \mathrm{C}$ 以上では減少が顕著にな り, $500^{\circ} \mathrm{C}$ で注とんど消失する. 従って, X 線回折測定 からは $400^{\circ} \mathrm{C}$ 近傍以上の熱処理で, $\mathrm{Fe} / \mathrm{Fe}-\mathrm{O}$ 積層膜の層 周期に影著な乱れが生じることがわかる.次に, Fig. 9 $\mathrm{Ke} / \mathrm{Fe}-\mathrm{O}$ 積層膜の熱処理に上る透磁率の変化を示す. 比較として $\mathrm{Fe}$ 単層膜の值を併記した. Fe 単層膜の透磁

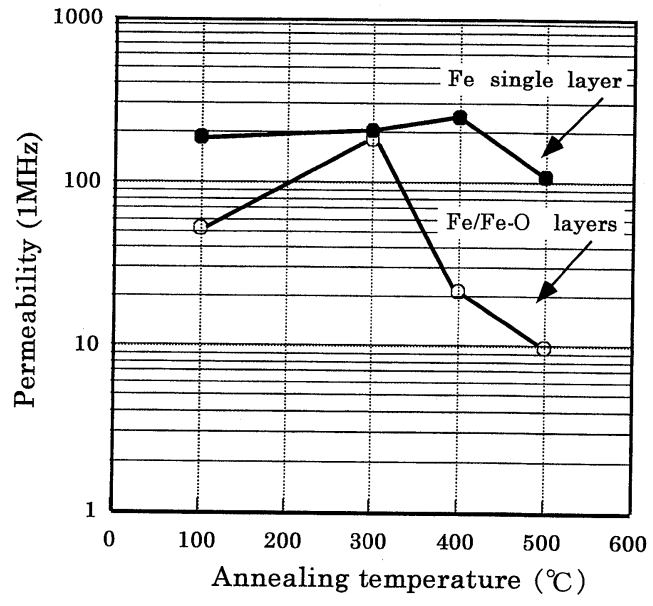

Fig. 9 Relation between annealing temperature and permeability.

率には大きな変化は見られない。一方, $\mathrm{Fe} / \mathrm{Fe}-\mathrm{O}$ 積層 膜は, $300^{\circ} \mathrm{C}$ の熱処理で透磁率が一度增加した後, $400^{\circ} \mathrm{C}$ 以上で急激に減少する. $300^{\circ} \mathrm{C}$ での軟磁気特性の 向上は，熱処理により基板のたわみ量が減少したことか ら, 主に膜の内部応力緩和が原因と考光られる. 一方, $400^{\circ} \mathrm{C}$ での急激な磁気特性の劣化は界面の乱れが， $\mathrm{Fe}-$ $\mathrm{O}$ 層を介した $\mathrm{Fe}$ 層間の磁気結合状態に変化を与えた結 果と考学られる，以上のよらに，X線回折で観察され た界面の乱れる熱処理温度と, 透磁率の劣化する温度が 一致していることから，金属/金属酸化物界面の層状態 を知る手がかりとして, 磁気測定が有用であることがわ かる.

これまで報告された $\mathrm{Fe}(7 \sim 10 \mathrm{~nm}) / \mathrm{SiO}_{2}(0.5 \sim 2.5$ $\mathrm{nm})$ 積層膜の軟磁気特性の耐熱処理温度が $250 \sim 300^{\circ} \mathrm{C}$ 程度である1)2)ことを考光ると，作製した $\mathrm{Fe} / \mathrm{Fe}-\mathrm{O}$ 人工 格子は, $\mathrm{SiO}_{2}$ よりも $\mathrm{Fe}$ 層中に酸素を奪われやすい $\mathrm{Fe}^{-}$ $\mathrm{O}$ 層で分断されているにも関わらず比較的高い熱安定 性を持っているといえる，この理由としては界面自由エ ネルギーの差, $\mathrm{Fe}-\mathrm{O}$ が結晶質を含んでいること, $\mathrm{Fe}-$ $\mathrm{O}$ 化合物が比較的生成自由エネルギー差が小さい $3 つ$ の安定相を持つことなどが考兄られるが, 詳細な機構解 明は今後の課題である.

\section{4. まとめ}

（M/M 化合物）積層膜の高速成膜法である PRS 法の プラズマ状態を検討し，作製した $\mathrm{Fe} / \mathrm{Fe}-\mathrm{O}$ 積層膜の界 面の熱変化について調べた。主な結果を以下に記す。

1）パルス状の $\mathrm{O}_{2}$ ガス導入により生じるプラズマ状 態は, 定常状態にある反応性スパッタリングのプラズマ 
状態と異なり, ガス導入直後, 及び停止直後において低 酸素プラズマ状態となる過渡状態を持つ. またパルス幅 が短くなるにつれ，低酸素プラズマ状態が支配的となる 傾向がある。またこの低酸素プラズマ状態で作製した $\mathrm{Fe}-\mathrm{O}$ 層は, $\mathrm{Fe}$ 層よりも速い成膜速度を持つ.

2）パルス幅の短い低酸素プラズマ状態を用いて, 連 続高速成膜した $[\mathrm{Fe}(4.6 \mathrm{~nm}) / \mathrm{Fe}-\mathrm{O}(0.4 \mathrm{~nm})]$ 積層膜 は, $\mathrm{X}$ 線回折的に明瞭な周期構造を持つ人工格子を形 成した。

3) $\mathrm{X}$ 線回折線強度と磁気特性の熱処理による変化 の比較から，作製した $\mathrm{Fe} / \mathrm{Fe}-\mathrm{O}$ 人工格子は, $\mathrm{Fe} / \mathrm{SiO}_{2}$ 並の界面熱安定性 $\left(300^{\circ} \mathrm{C}\right)$ を持つことがわかった。 たそれぞれの測定法の結果の一致から，金属/酸化物界 面の熱処理による変化の間接的評価法として, 磁気測定 法が有用であることがわかった。

\section{謝辞}

研究の実施に際し，プラズマ分光に関する有益な議論
をして頂いた，松下電器産業中央研究所，真鍋良夫，北 川雅俊の両博士に心からの感謝の念を表します.

な括本研究は通商産業省工業技術院科学技術開発制度 「シナジーセラミックスの研究開発」の一環としてファ インセラミックス技術研究組合が新エネルギー・産業技 術総合開発機構より委託を受け, シナジーセラミックス に所属する著者らによって行われたものである.

\section{[文献〕}

1) T. Kobayashi: J. Appl. Phys., 73 (1993) 858.

2) M. Senda and Y. Nagai: J. Appl. Phys., 65 (1989) 1238.

3) H. Sakakima, K. Osano, K. Ihra and M. Satomi: J. Magn. Magn. Mat., 93 (1991) 349.

4) H. Fujimori, N. Hasegawa, N. Kaoka, S. Nagata and S. Yamaguchi: J. Magn. Magn. Mat., 121 (1993) 42.

5) R. R. Ruf and R. J. Gambino: J. Appl. Phys., 55 (1984) 2628. 